Dept. Animal Medicine, Clinical Laboratory Diagnosis,

Fac. of Vet. Med., Assiut University, Assiut.

\title{
FIELD INVESTIGATION OF SWINE MYCOBACTERIOSIS WITH SERODIAGNOSTIC TRIAL USING FIBRONECTIN-BINDING PROTEIN (AG85-B)
}

(With 5 Tables and One Figure)

By

\section{A.M. MOHAMED; E.A. NASR* and Y.A. SOLIMAN**}

* Bacterial Diagnostic Product, Vet. Serum and Vaccine Research Institute, Abbassia, Cairo.

** Central Laboratory for Quality Control of Veterinary Biologics, Abbassia, Cairo.

(Received at 17/9/2008)

دراسة ميدانيه لمرض الميكوبكتريوزس في الخنازير في مصر مع عمل بالئل

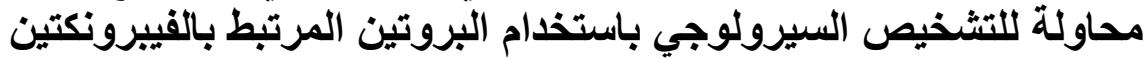
(Ag85-B)

عمرو محد عبل الفتاح محمد ، عصام أمبن نصر ، بيوسف عادل سلييان الهدف من هذة الدراسة هو دراسة نسبة وطبيعة مرض الميكوبكتريوزس في الخنازير التي يتم

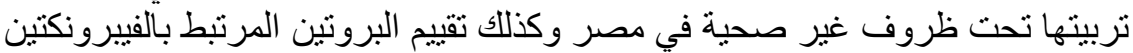
Ag85-B

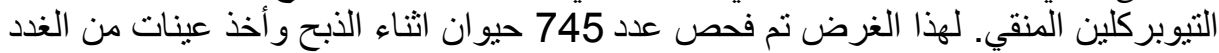

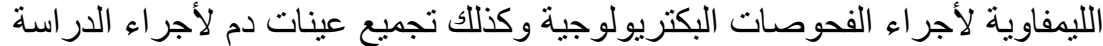

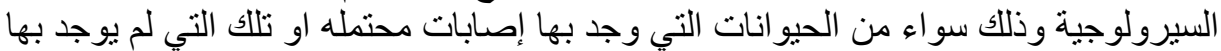

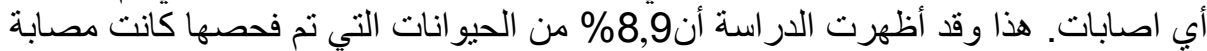

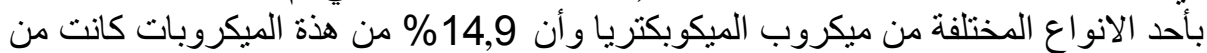

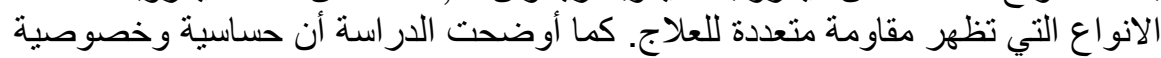

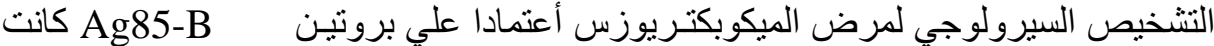

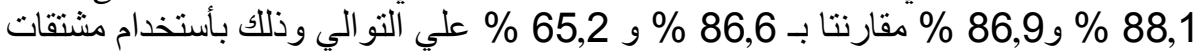

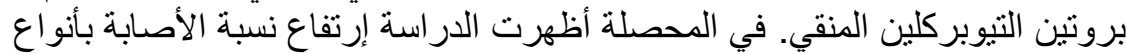

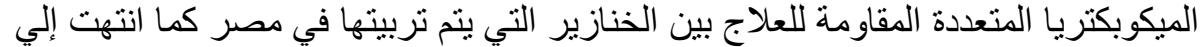

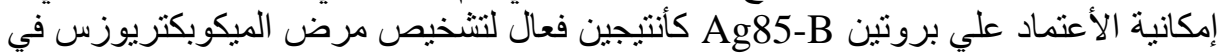

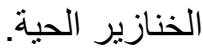




\section{SUMMARY}

The aim of the current study was to investigate the prevalence and the nature of swine mycobacteriosis in pigs raised under poor hygienic conditions in Egypt and to evaluate fibronectin-binding protein (Ag85B) in serological detection of the disease in living pigs. A total of 745 slaughtered pigs were examined for suspected mycobacterial lesions. Lymph node specimens for mycobacteriological examination and blood samples for serological evaluation of Ag85-B were collected from both suspected and lesion-free pigs. The study revealed that $8.9 \%$ of examined pigs were infected with different Mycobacterium species, of which, $14.9 \%$ were multi-drug resistant. Serological evaluation of Ag85-B revealed an overall sensitivity and specificity of $88.1 \%$ and $86.9 \%$, respectively; as compared to $86.6 \%$ and $65.2 \%$ of tuberculin PPD-based serodignosis. In conclusion, the study revealed high burden of drug resistant mycobacterial infections in Egyptian swine and showed the reliability of $\mathrm{Ag} 85-\mathrm{B}$ as a potential candidate for serological diagnosis of swine mycobacteriosis in living pigs.

Key words: Swine mycobacteriosis, serological diagnosis, Ag85-B, tuberculin PPD.

\section{INTRODUCTION}

During the last two decades, infection with tuberculous, as well as non-tuberculous mycobacteria has become increasingly important among human beings and farm animals (Bottger, 1994; Butler et al., 1993). The pandemic of HIV infection in many part of the world, as well as the emergence of multi-drug resistant (MDR) tuberculosis have complicated the disease control process (Wayne and Sramek, 1992). Mycobacterium tuberculosis complex and Mycobacterium aviumintracellulare complex were the most frequently isolated mycobacteria from AIDS patients (Benson, 1994; LoBue et al., 2001). Origin of mycobacterial infections in humans is still a matter of speculation. Previous studies have shown that the pigs were among important sources of mycobacterial infections to man (Bono et al., 1995). Little information is available about the burden and nature of mycobacterial infections in swine, especially those raised under poor hygienic conditions.

Diagnosis of swine mycobacteriosis, erroneously described as swine "tuberculosis", in living pigs has been a major hindrance in efforts 
to study the disease. Clinical signs of diagnostic value are usually absent and reliability of the tuberculin skin test has been questioned (Songer et al., 1980). Majority of cases were diagnosed only during regular meat inspection in slaughterhouses by detection of suspected mycobacterial lesions in carcasses (Brown and Neuman, 1979; Dey and Parham, 1993). However, many cases can escape post-mortem examination especially during early stage of infection (Matlova et al., 2005; Windsor et al., 1984); also in some cases, it is difficult to differentiate lesions caused by mycobacterial infections from other lesions (Katsumi et al., 1991; Makrai et al., 2005). Unreliability of the tuberculin skin test for diagnosis of swine tuberculosis (Songer et al., 1980; Thoen et al., 1979) has drawn attention towards serodiagnosis as an alternative for diagnosis of swine mycobacteriosis in living animals.

Culture filtrates prepared from tuberculous Mycobacterium spp. are complex mixture of several antigenic proteins (Daniel and Anderson, 1978). A major portion of the secreted proteins in M. tuberculosis and $M$. bovis BCG culture filtrate is formed of the antigen 85 (Ag85) complex, a 30-32 kDa family of three fibronectin-binding proteins (Ag85-A, Ag85-B, and Ag85-C) (Wiker and Harboe, 1992). All members of Ag85 complex possess a mycoloyltransferase enzyme activity required for the biogenesis of cord factor (Belisle et al., 1997), a dominant structure necessary for maintaining cell wall integrity (Jackson et al., 1999). The Ag85 complex molecules have been reported to be the dominantly secreted antigens expressed by nearly all mycobacterial species (Wiker and Harboe, 1992). Ag85 complex molecules are crossreactive antigens and are highly conserved among Mycobacterium spp. and thus revealed species specific properties (Salata et al., 1991; Schorey et al., 1996).

The current study was undertaken to determine the prevalence and nature of mycobacterial infections in Egyptian swine that are raised under poor hygienic conditions, as a potential source of infection to other farm animals and humans. Furthermore, the study was aimed to evaluate the feasibility of Ag85-B as a potential candidate for serological screening of swine mycobacterial infections in living animals.

\section{MATERIALS and METHODS}

\section{Animals and post-mortem examination}

A total of 745 pigs were examined during the period from April 2004 till October 2005. Animals were subjected to post-mortem examination after slaughter at the Central Swine Abattoir, Basatin, 
Cairo, Egypt for suspected mycobacterial lesions. All pigs were carefully examined post-mortem for suspected mycobacterial lesions. In the course of post-mortem examination, retropharyngeal, sub-maxillary, parotid, bronchial, mediastinal, mesenteric and pre-scapular lymph nodes were examined visually and by palpation in situ. Specimens from all suspected lesions, as well as lesion-free lymph nodes were collected aseptically and subjected for conventional mycobacteriological examination. Blood samples were collected at the time of slaughter from all examined animals and were allowed to clot and then were centrifuged for separation of sera that were stored at $-20^{\circ} \mathrm{C}$ till used for serological evaluation.

\section{Conventional bacteriological examination}

Mycobacterium spp. isolation was carried out as previously described (Kent and Kubica, 1985). Briefly, tissue samples from collected lymph nodes were homogenized in a tissue-grinding mortar with $5 \mathrm{ml}$ of sterile saline. Tissue homogenates were centrifuged at 3000 $\mathrm{g}$ for 15 minutes. The supernatant fluid was discarded and the sediment was treated with $2 \mathrm{ml}$ of $4 \%$ sulphuric acid for 15 minutes, and then washed twice with sterile saline by centrifuging at $3000 \mathrm{~g}$ for 15 minutes. The sediment was then neutralized with $4 \% \mathrm{NaOH}$ containing phenol red indicator and immediately inoculated onto LöwensteinJensen (L-J) media (Biolife, Milano, Italy) and incubated at $37^{\circ} \mathrm{C}$ for up to 8 weeks. Smears of suspected colonies were stained with Ziehl Neelsen stain to assess acid-fastness and morphology of bacteria. Colony morphology, and pigment production under dark and light conditions were examined. Conventional biochemical tests were performed as previously described (Kent and Kubica, 1985), and those included niacin accumulation, nitrate reduction, Tween 80 hydrolysis, urease activity, iron uptake, tolerance to $5 \%$ sodium chloride, growth on thiophene-2carboxylic acid hydrazide (T2H) and ability to grow on MacConkey agar.

\section{Antimicrobial susceptibility}

All isolated Mycobacterium spp. were evaluated for antimicrobial susceptibility using the standard macrodilution method with radiometric broth and evaluated on a BACTEC 460 instrument (Becton Dickinson, Sparks, MD.) (Siddiqi et al., 1993). Antimicrobial susceptibility testing included the first-line anti-mycobacterial agents; streptomycin, isoniazid, ethambutol and rifampicin. Multi-drug resistant (MDR) strains were defined as being resistant to two or more of the 
primary drugs (isoniazid and rifampicin) used for the treatment of tuberculosis (Raviglione and Smith, 2007).

\section{Serological examination}

\section{a) Bacterial strains and preparation of antigens}

The $M$. bovis AN5 standard strain (supplied by the Central Veterinary Laboratory, Weybridge, England) was used throughout the study. Cultures were grown to log phase in Middlebrook 7H9 liquid medium (Difco, Detroit, MI), supplemented with Middlebrook ADC enrichment (Difco), then were sub-cultured as surface pellicles on the wholly synthetic Sauton medium for 3-8 weeks. Tuberculin purified protein derivatives (PPD) and fibronectin-binding antigen (Ag85-B) were prepared from the culture filtrate $(\mathrm{CF})$ of $M$. bovis AN5. The PPD antigen was prepared from the heated $\mathrm{CF}$ as previously described (Landi, 1984), while the native Ag85-B antigen was prepared from the unheated CF according to Salata et al. (1991).

\section{b) Enzyme-linked immunosorbent assay (ELISA)}

For serological evaluation, indirect ELISA was carried out using both Ag85-B and tuberculin PPD antigens as previously described (Sada et al., 1990) with some modifications. Briefly, Immulon II 96 microtiter plates (Nunc, Copenhagen. Denmark) were coated with either Ag85-B $(0.5 \mu \mathrm{g} / 100 \mu \mathrm{l}$ carbonate buffer, $\mathrm{pH} 9.6)$ or tuberculin PPD $(5 \mu \mathrm{g} / 100 \mu \mathrm{l}$ carbonate buffer, $\mathrm{pH}$ 9.6, containing $1 \%$ carbodiamide) and were incubated for 24 hours. The plates were then decanted and blocked with $2 \%$ bovine serum albumin for $2 \mathrm{~h}$. $100 \mu \mathrm{l}$ of $1 / 100$ diluted serum was added to each well and plates were incubated at $37^{\circ} \mathrm{C} / 2 \mathrm{~h}$. Horseradish peroxidase-conjugated anti-pig was used as a secondary antibody. The substrate used was OPD. The plates were washed four times between each step with PBS containing $0.1 \%$ Tween 20 . All reaction mixtures were set in duplicate, with the mean value being used for recording and calculations. Out of the healthy animals (lesions-free), 28 animals were proved free from any mycobacterial infections after precise mycobacteriological examination and their sera were used as healthy control subjects. Results were read on SOFTmax PRO ELISA reader (Molecular Device Corporation, California) at a wave length of $450 \mathrm{~nm}$.

\section{c) Evaluation of tests and statistical analysis}

Analysis of mean optical density (OD) values of both antigens with different Mycobacterium-infected and non-infected animal groups were carried out using Statistical Package for Social Sciences (SPSS) version 10.0. Data were presented as the mean OD \pm SD and the OD range. The optimal cut-off points for distinguishing between positive and 
negative results for both antigens were determined by Receiver Operating Characteristic (ROC) curve analysis using Analyse-it Software (www.analyse-it.com) (Surujballi et al., 2002). The ROC curve [a plot of the true positive rate (sensitivity) against the false positive rate (1-specificity) that is obtained at each cut-off point] was constructed and the area under the curve (AUC) value was calculated as a measure of the accuracy of the test. The tested antigens were evaluated in terms of accuracy index, sensitivity, specificity, and positive and negative predictive values as described elsewhere (Smith, 1995).

\section{RESULTS}

\section{Post-mortem and bacteriological examination}

Suspected lesions of various sizes were detected in 110 (14.8\%) of 745 examined swine carcasses (Table 1). Most lesions were yellowish white to gray foci of nodular appearance with size range of $2-5 \mathrm{~cm}$ in diameter and were detected in sub-maxillary, bronchial and mesenteric lymph nodes (Table 2).

Conventional mycobacteriological examination revealed positive cultures in $67(60.9 \%)$ out of the 110 suspected tuberculous lesions and $23(3.6 \%)$ out of the 635 lesion-free specimens. From these positive cultures, $33.3 \%$ were tuberculous Mycobacterium species (M. tuberculosis and M. bovis), $41.1 \%$ were non-tuberculous Mycobacterium species $(M$. avium, $M$. intracellulare and $M$. scrofulaceum), while $25.6 \%$ of the positive cultures were nonmycobacterial species (Table 1,2).

\section{Antimicrobial susceptibility}

The antibiogram study revealed that $32.8 \%, 38.8 \%, 29.9 \%$ and $23.9 \%$ of all isolated Mycobacterium species were resistant to streptomycin, isoniazid, ethambutol and rifampicin, respectively. MDR profile was detected in $14.9 \%$ of all tested isolates (Table 3).

\section{Serological evaluation of Ag85-B and PPD}

The cutoff values for Ag85-B and tuberculin PPD were 0.144 and 0.212 , respectively. Using these cutoff values, Ag85-B detected 59 $(88.1 \%)$ out of 67 serum samples from suspected infected animals that were culture positive and conventionally identified as Mycobacterium species, and $3(13.04 \%)$ out of the 23 non-mycobacterium species infected animals with an overall accuracy index, sensitivity, specificity, positive predictive value, and negative predictive value of $85.5 \%$, $88.1 \%, 86.9 \%, 95.2 \%$, and $71.4 \%$, respectively. On the other hand, 
tuberculin PPD were able to detect $58(86.6 \%)$ out of 67 samples that were culture positive and conventionally identified as Mycobacterium species, and 8 (34.8\%) out of 23 samples of non-mycobacterium species with an overall accuracy index, sensitivity, specificity, positive predictive value, and negative predictive value of $81.1 \%, 86.6 \%, 65.2 \%$, $87.9 \%$, and $62.5 \%$, respectively (Tables 4 and 5). The AUCs for the Ag85-B and PPD antigens were 0.944 and 0.934, respectively. This shows that in more than $93 \%$ of cases an animal giving a result above the cutoff value was correctly identified (Fig.1).

Fig. 1: ROC curve obtained from the analysis of ELISA data from suspected sera against Ag85-B and PPD antigens. The false positive rate (1-specificity) is plotted against the true positive rate (sensitivity) for each cutoff point. (A) Optimal cutoff value* and area under the curve (AUC) of Ag85-B; (B) Optimal cutoff value* and AUC of tuberculin PPD. 
Table 1: Prevalence of swine mycobacteriosis based on conventional mycobacteriological examination of collected specimens from slaughtered pigs.

Mycobacteriological Identification

Postmortem

Examination

$\begin{array}{ccc}\text { Positive } & \text { Tuberculous } & \text { Non-tuberculous } \\ \text { cultures } & \text { Mycobacterium } & \text { Mycobacterium } \\ & \text { species } & \text { species }\end{array}$

$\%$

$\mathrm{N} \quad \%$

$\mathrm{N}$

$\%$

Suspected lesions

110

(14.8\%)

$67 \quad 60.9$

30

44.7

26

38.8

11

16.4

Lesion free

\begin{tabular}{ccccccccc}
635 & 23 & 3.6 & - & - & 11 & 47.8 & 12 & 52.2 \\
$(86.2 \%)$ & 90 & 12.1 & 30 & 33.3 & 37 & 41.1 & 23 & 25.6 \\
\hline $\begin{array}{c}\text { Total } \\
745\end{array}$ & 90
\end{tabular}


Table 2: Predictive values of suspected lesions regarding positive cultures for different Mycobacterium species.

\begin{tabular}{|c|c|c|c|c|c|c|c|c|c|c|c|}
\hline \multirow{4}{*}{$\begin{array}{l}\text { Suspected } \\
\text { Lesions } \\
\text { (n) }\end{array}$} & \multirow{4}{*}{$\begin{array}{l}\text { Positive } \\
\text { cultures }\end{array}$} & \multicolumn{10}{|c|}{$\begin{array}{l}\text { Mycobacterium } \\
\text { species }\end{array}$} \\
\hline & & \multicolumn{4}{|c|}{$\begin{array}{c}\text { Tuberculous } \\
\text { Mycobacterium species }\end{array}$} & \multicolumn{6}{|c|}{$\begin{array}{c}\text { Non-tuberculous } \\
\text { Mycobacterium species }\end{array}$} \\
\hline & & \multicolumn{2}{|c|}{$\begin{array}{c}M . \\
\text { tuberculosis }\end{array}$} & \multicolumn{2}{|c|}{$\begin{array}{c}M . \\
\text { bovis }\end{array}$} & \multicolumn{2}{|c|}{ M. avium } & \multicolumn{2}{|c|}{$\begin{array}{c}\text { M. } \\
\text { intracellulare }\end{array}$} & \multicolumn{2}{|c|}{$\begin{array}{c}M . \\
\text { scrofulaceum }\end{array}$} \\
\hline & & $\mathrm{n}$ & $\%$ & $\mathrm{~N}$ & $\%$ & $\mathrm{n}$ & $\%$ & $\mathrm{n}$ & $\%$ & $\mathrm{n}$ & $\%$ \\
\hline $\begin{array}{l}\text { Sub-maxillary } \\
\text { lymph node } \\
\text { (40) }\end{array}$ & 15 & 3 & 20 & 4 & 26.6 & 3 & 20 & 1 & 6.7 & 1 & 6.7 \\
\hline $\begin{array}{l}\text { Bronchial } \\
\text { Lymph node } \\
\qquad(29)\end{array}$ & 20 & 2 & 10 & 5 & 25 & 4 & 20 & 3 & 15 & 2 & 10 \\
\hline $\begin{array}{l}\text { Mesenteric } \\
\text { lymph node } \\
\text { (35) }\end{array}$ & 26 & 5 & 19.2 & 6 & 23.1 & 4 & 15.4 & 3 & 11.5 & 5 & 19.2 \\
\hline $\begin{array}{l}\text { Generalized } \\
\text { lesions } \\
\text { (6) }\end{array}$ & 6 & 2 & 33.3 & 3 & 50 & 0 & - & 0 & - & 0 & - \\
\hline $\begin{array}{c}\text { Total lesions } \\
(110)\end{array}$ & 67 & 12 & 17.9 & 18 & 26.9 & 11 & 16.4 & 7 & 10.4 & 8 & 11.9 \\
\hline
\end{tabular}

- Positive mycobacterial infections predictive value of suspected lesions. 
Table 3: Antibiogram resistance of mycobacterial isolates to firstline anti-mycobacterial drugs.

\begin{tabular}{|c|c|c|c|c|c|}
\hline $\begin{array}{l}\text { Mycobacterial } \\
\text { isolates }\end{array}$ & Streptomycin & Isoniazid & Ethambutol & Rifampicin & $\operatorname{MDR}^{a}$ \\
\hline $\begin{array}{l}\text { M. } \\
\text { tuberculosis }\end{array}$ & $5 / 18(28.3 \%)$ & $\begin{array}{c}6 / 18 \\
(33.3 \%)\end{array}$ & $5 / 18(28.3 \%)$ & $\begin{array}{c}3 / 18 \\
(16.6 \%)\end{array}$ & $\begin{array}{c}3 / 18 \\
(16.6 \%)\end{array}$ \\
\hline M. bovis & $6 / 12(50 \%)$ & $\begin{array}{c}7 / 12 \\
(58.3 \%)\end{array}$ & $5 / 12(41.6 \%)$ & $\begin{array}{c}4 / 12 \\
(33.3 \%)\end{array}$ & $\begin{array}{l}3 / 12 \\
(25 \%)\end{array}$ \\
\hline $\begin{array}{l}\text { M. avium } \\
\text { complex }\end{array}$ & $\begin{array}{c}11 / 37 \\
(29.7 \%)\end{array}$ & $\begin{array}{c}13 / 37 \\
(35.1 \%)\end{array}$ & $10 / 37(27 \%)$ & $\begin{array}{c}9 / 37 \\
(24.3 \%)\end{array}$ & $\begin{array}{c}4 / 37 \\
(10.8 \%)\end{array}$ \\
\hline Total & $\begin{array}{c}22 / 67 \\
(32.8 \%)\end{array}$ & $\begin{array}{c}26 / 67 \\
(38.8 \%)\end{array}$ & $20 / 67(29.9 \%)$ & $\begin{array}{c}16 / 67 \\
(23.9 \%)\end{array}$ & $\begin{array}{c}10 / 67 \\
(14.9 \%)\end{array}$ \\
\hline
\end{tabular}

${ }^{a}$ Multi-drug resistant strains (resistant to any two or more of the first-line antimycobacterial agents isoniazid and rifampicin) 
Table 4. Serodiagnosis of swine mycobacteriosis by ELISA detection of anti-mycobacterial IgG in swine sera using Ag85-B and tuberculin PPD antigens.

\begin{tabular}{|c|c|c|c|c|c|c|c|}
\hline \multirow{2}{*}{$\begin{array}{c}\text { Conventionally } \\
\text { Identified } \\
\text { Mycobacterium spp. }\end{array}$} & \multirow{2}{*}{$\begin{array}{l}\text { Total } \\
\text { No. of } \\
\text { isolates }\end{array}$} & \multicolumn{3}{|c|}{ Ag85-B } & \multicolumn{3}{|c|}{ PPD antigen } \\
\hline & & $\begin{array}{l}\text { Mean OD } \pm S D \\
\text { (OD range) }\end{array}$ & $\begin{array}{l}\text { Cutoff } \\
\text { point }\end{array}$ & $\begin{array}{l}+\mathrm{ve} \\
\text { cases }\end{array}$ & $\begin{array}{l}\text { Mean OD } \pm S D \\
\text { (OD range) }\end{array}$ & $\begin{array}{l}\text { Cutoff } \\
\text { point }\end{array}$ & +ve cases \\
\hline M. bovis & 12 & $\begin{array}{c}0.546 \pm 0.156 \\
(0.209-0.748)\end{array}$ & & 12 & $\begin{array}{c}0.534 \pm 0.145 \\
(0.203-0.821)\end{array}$ & & 11 \\
\hline M. tuberculosis & 18 & $\begin{array}{c}0.560 \pm 0.203 \\
(0.203-0.862)\end{array}$ & & 18 & $\begin{array}{c}0.544 \pm 0.131 \\
(0.323-0.794)\end{array}$ & & 18 \\
\hline $\begin{array}{l}\text { M. avium complex } \\
\text { Suspected lesions }\end{array}$ & 26 & $\begin{array}{c}0.380 \pm 0.184 \\
(0.074-0.674)\end{array}$ & & 20 & $\begin{array}{c}0.288 \pm 0.122 \\
(0.073-0.512)\end{array}$ & & 20 \\
\hline Lesion-free & 11 & $\begin{array}{c}0.327 \pm 0.133 \\
(0.124-0.494)\end{array}$ & 0.144 & 9 & $\begin{array}{c}0.376 \pm 0.126 \\
(0.142-0.594)\end{array}$ & 0.212 & 9 \\
\hline $\begin{array}{l}\text { Sub-total } \\
\text { Non-Mycobacterium spp. }\end{array}$ & 67 & & & 59 & & & 58 \\
\hline Suspected lesion & 11 & $\begin{array}{c}0.131 \pm 0.028 \\
(0.089-0.179)\end{array}$ & & 2 & $\begin{array}{c}0.184 \pm 0.107 \\
(0.086-0.376)\end{array}$ & & 4 \\
\hline Lesion-free & 12 & $\begin{array}{c}0.135 \pm 0.040 \\
(0.076-0.242)\end{array}$ & & 1 & $\begin{array}{c}0.175 \pm 0.066 \\
(0.095-0.272)\end{array}$ & & 4 \\
\hline Total & 90 & & & 62 & & & 66 \\
\hline
\end{tabular}


Table 5: Evaluation of Ag85-B as compared to tuberculin PPD antigen for serodiagnosis of swine mycobacteriosis

\begin{tabular}{lcc}
\hline \multicolumn{1}{c}{$\begin{array}{c}\text { Evaluation } \\
\text { parameters }\end{array}$} & Antigen 85-B & Tuberculin PPD \\
\hline Accuracy Index & $85.5 \%$ & $81.1 \%$ \\
Sensitivity & $88.1 \%$ & $86.6 \%$ \\
Specificity & $86.9 \%$ & $65.2 \%$ \\
Positive predictive value & $95.2 \%$ & $87.9 \%$ \\
Negative predictive value & $71.4 \%$ & $62.5 \%$ \\
\hline
\end{tabular}

\section{DISCUSSION}

Swine mycobacteriosis results in severe economical losses in a number of countries and represents a public health threat. Average prevalence of swine mycobacteriosis in examined slaughtered pigs as revealed in the present study was $8.9 \%$ (67 out of 745), which is unexpectedly high as compared to $0.4 \%$ in USA (Payeur and Songer, 1992) and $0.5 \%$ in Europe (Komijn et al., 1999), taking into account the fact that this prevalence is based on the isolation of Mycobacterium species from suspected tuberculous lesions as well as lesion-free specimens of examined carcasses. High prevalence of both tuberculous and non-tuberculous mycobacterial infections among pigs as revealed in the current study could be attributed to poor hygienic standards of pig farming in Egypt, where feeding on household and hospital wastes as well as wastes of animal and chicken farms is a common practice. This denotes the importance of these animals as a potential reservoir for many mycobacterial infections that can infect other farm animals and humans. In addition, high multi drug resistant (MDR) profile (14.9\%) of isolated mycobacterial strains as documented in the current study (Table 3) intensifies the potential risk of these animals as source of severe type of MDR infections with both tuberculous and non-tuberculous Mycobacterium spp. to humans. This signify public health concern especially among immunodeficiency virus-positive and other immunocompromized individuals (Leao et al., 1999). Moreover, economical losses due to swine mycobacteriosis are not only restricted to the condemnation of pig meat, head and visceral organs at abattoir inspection points due to tuberculous lesions, but also of being a source of bovine tuberculosis to other farm animals via dissemination of Mycobacterium bovis in the environment (Phillips et al., 2003). In addition, dissemination of atypical mycobacterium species 
(Mycobacterium avium complex) can sensitize cattle, which results in nonspecific reaction to PPD tuberculin skin test with the subsequent economical losses from the destruction of false positive reactor cattle (Matlova et al., 2005; Pollock et al., 2000).

In the present study, most suspected tuberculous lesions were detected in sub-maxillary, bronchial and mesenteric lymph nodes. However, sub-maxillary lymph nodes showed relatively low predictive value $(30 \%)$ regarding the positive mycobacterial cultures as compared to that of bronchial (55.2\%) and mesenteric (65.7\%) lymph nodes (Table 2 ). The low predictive value of sub-maxillary lymph nodes could be attributed to the presence of other non-mycobacterial infections caused by organisms found in soil and frequently infect pigs as Rhodococcus equi that results in similar localized lesions in sub-maxillary lymph nodes (Makrai et al., 2002, Makrai et al., 2005). Most lesions (92/110) were $2-5 \mathrm{~cm}$ in diameter and of yellowish white to grey foci of nodular appearance with central caseation, often calcified and mostly surrounded by a fibrous connective tissue, which is consistent with previous reports (Gortazar et al., 2003; Matlova et al., 2005), and indicated that most tuberculous infections in pigs are of noninvasive type and the site of infection could easily be concealed by a protective fibrous tissue preventing further spread of the infection. However, 18 cases showed severe lesions of proliferate to purulent type, of which six were generalized, most of them identified as Mycobacterium tuberculosis complex ( 2 M. bovis and 3 M. tuberculosis). On the other hand, 11 mycobacterial isolates were recovered from lesion-free specimens of apparently healthy pigs, which could indicate early-stage infection, noticeably, all of which were identified as non-tuberculous Mycobacterium species. Previous studies have documented the isolation of different pathogenic mycobacterial species from healthy slaughter swine without any apparent lymph node or tissue lesions (Matlova et al., 2005; Songer et al., 1980; Windsor et al., 1984).

Tuberculin skin testing is unreliable for diagnosis of swine tuberculosis (Thoen et al., 1979). Therefore, diagnosis of swine mycobacteriosis and studying of its prevalence in live animals is usually impossible and it still based mainly on post-mortem findings by meat inspectors (Dey and Parham, 1993). In the current study, the fibronectinbinding protein (Ag85-B) was purified and evaluated serologically, in comparison with the tuberculin PPD, as a potential candidate for rapid screening of swine mycobacteriosis in living pigs. Serodiagnosis of swine mycobacteriosis using Ag85-B and tuberculin PPD have showed 
that both Ag85-B and tuberculin PPD antigens have comparable sensitivity (88.1 and 86.6, respectively), however, the specificity, positive predictive values and negative predictive values for Ag85-B were higher $(86.9 \%, 95.2 \%$ and $71.4 \%$, respectively) than that $(65.2 \%$, $87.9 \%$ and $62.5 \%$, respectively) of tuberculin PPD (Table 5). The higher specificity and positive predictive value of Ag85-B as compared to that of tuberculin PPD could be attributed to the fact that PPD is a protein complex that contain many shared antigenic epitopes with other nonmycobacterial organism, which greatly affect its specificity in diagnosis of mycobacterial infection (Fifis et al., 1991). On the other hand, Ag85 complex molecules have been reported to be the dominant secreted antigens that are highly specific and conserved among Mycobacterium spp. and thus revealed species specific properties (Salata et al., 1991; Schorey et al., 1996; Silver et al., 1995). In previous studies, the use of multiple overlapping peptides corresponding to the entire sequence of the antigen 85 revealed the presence of at least seven T-cell determinants with high homology between the antigen 85 purified from both $M$. bovis $B C G$ and $M$. tuberculosis (Silver et al., 1995). The same epitopes were found in the $M$. avium strains but with much less homology indicating that the antigen could have potential diagnostic capabilities for both $M$. tuberculosis complex as will as $M$. avium intracellulare complex (Schorey et al., 1996; Secott et al., 2001).

The ability of Ag85-B antigens, as revealed in the current study (Table 4), to detect mycobacterial infections in 9 cases out of 11 lesionfree apparently healthy pigs that were proved infected by conventional mycobacteriological examination, indicates its feasibility in early detection of swine mycobacteriosis.

In conclusion, high burden of swine infection with multi drug resistant strains of both tuberculous and non-tuberculous Mycobacterium species (mainly M. avium complex) clearly denote the high risk factor of pigs as a dangerous threat to public health and other farm-animals industry via dissemination of these organisms in the environment. Ag85B could be a good candidate for rapid and early serological detection of both tuberculous and non-tuberculous mycobacterial infections in living pigs.

\section{REFERENCES}

Belisle, J.T.; Vissa, V.D.; Sievert, T.; Takayama, K.; Brennan, P.J. and Besra., G.S. (1997): Role of the major antigen of Mycobacterium tuberculosis in cell wall biogenesis. Science 276: $1420-422$. 
Benson, C.A. (1994): Disease due to the Mycobacterium avium complex in patients with AIDS: epidemiology and clinical syndrome. Clinical Infectious Diseases 18: 218-222.

Bono, M.; Jemmi, T.; Bernasconi, C.; Burki, D.; Telenti, A. and Bodmer, T. (1995): Genotypic characterisation of Mycobacterium avium strains recovered from animals and their comparison to human strains. Applied and Environmental Microbiology 61: 371-373.

Bottger, E.C. (1994): Mycobacterium genavense: an emerging pathogen. European Journal of Clinical Microbiology and Infectious Diseases 13: 932-936.

Brown, J. and Neuman, M.A. (1979): Lesions of swine lymph nodes as a diagnostic test to determine Mycobacterial infection. Applied and Environmental Microbiology 37: 740-743.

Butler, W.R.; O'Connor, S.P.; Yakrus, M.A.; Smithwick, R.W.; Plikaytis, B.B.; Moss, C.W.; Floyd, M.M.; Woodley, C.L.; Kilburn, J.O. and Vadney, F.S. (1993): Mycobacterium celatum sp. nov. International Journal of Systemic Bacteriology 43: 539-548.

Daniel, T.M. and Anderson, P.A. (1978): The isolation by immunosorbent affinity chromatography and physicochemical characterization of Mycobacterium tuberculosis antigen 5. American Review of Respiratory Diseases 117: 533-539.

Dey, B.P. and Parham, G.L. (1993): Incidence and economics of tuberculosis in swine slaughtered from 1976 to 1988-food animal economics. Journal of American Veterinary Medicine Association 203: 516-519.

Fifis, T.; Castopoulos, C.; Radford, A.J.; Bacic, A. and Wood, P.R. (1991): Purification and characterization of major antigens of a Mycobacterium bovis culture filtrate. Infection and Immunity 59: 800-807.

Gortazar, C. Vicente, J. and Gavier-Widen, D. (2003): Pathology of bovine tuberculosis in the European wild boar (Sus scrofa). Veterinary Record 152: 779-780.

Jackson, M.; Raynaud, C.; Lane'elle, M.A.; Guilhot, C.; Laurent-Winter, C.; Ensergueix, D.; Gicquel, B. and Daffe', M. (1999): Inactivation of the antigen $85 \mathrm{C}$ gene profoundly affects the mycolate content and alters the permeability of the Mycobacterium tuberculosis cell envelope. Molecular Microbiology 31: 1573-1587. 
Katsumi, M.; Kodama, N.; Miki, Y.; Hiramune, T.; Kikuchi, N.; Yanagawa, R. and Nakazawa, A.M. (1991): Typing of Rhodococcus equi isolated from submaxillary lymph nodes of pigs in Japan. Zentbl. Veterinarmed. B 38: 299-302.

Kent, P.T. and Kubica, G.P. (1985): Public Health Mycobacteriology. A Guide for the level III Laboratory. US Department of Health and Human Services publication, Centers for Disease Control and Prevention, Atlanta, GA, USA.

Komijn, R.E.; De Haas, P.E.W.; Schnider, M.M.E.; Eger, T., Nieuwenhuijs, J.H.M., Van Den Hoek, R.J., Bakker, D.; Van Zijd Erveld, F.G. and Soolingen, D.V. (1999): Prevalence of Mycobacterium avium in slaughter pigs in The Netherlands and comparison of IS1245 restriction fragment length polymorphism patterns of porcine and human isolates. Journal of Clinical Microbiology 37: 1254-1259.

Landi, S. (1984): Production and standardization of tuberculin. In The Mycobacteria. Marcel Dekker, New York, 505-535.

Leao, S.C.; Briones, M.R.S.; Sircili, M.P.; Balian, S.C.; Mores, N. and Ferreira-Neto, J.S. (1999): Identification of two novel Mycobacterium avium allelic variants in pig and human isolates from Brazil by PCR-restriction enzyme analysis. Journal of Clinical Microbiology 37: 2592-2597.

LoBue, P.A.; Peter, C.; Tracy, M. and Moser, K. (2001): Concurrent Mycobacterium tuberculosis and Mycobacterium bovis infections in a patient with AIDS. International Journal of Tuberculosis and Lung Diseases 5: 1164-1165.

Makrai, L.; Takai, S.; Tamura, M.; Tsukamoto, A.; Sekimoto, R.; Sasaki, Y.; Kakuda, T.; Tsubaki, S.; Varga, J.; Fodor, L.; Solymosi, N. and Major, A. (2002): Characterization of virulence plasmid types in Rhodococcus equi isolates from foals, pigs, humans and soil in Hungary. Veterinary Microbiology 88: 377-384.

Makrai, L.; Takayama, S.; Dénes, B.; Hajto's, I.; Sasaki, Y.; Kakuda, T.; Tsubaki, S.; Major, A.; Fodor, L.; Varga, J. and Takai, S. (2005): Characterization of Virulence Plasmids and Serotyping of Rhodococcus equi Isolates from Submaxillary Lymph Nodes of Pigs in Hungary. Journal of Clinical Microbiology 43: 12461250.

Matlova, L.; Dvorska, L.; Ayele, W.Y.; Bartos, M.; Amemori, T. and Pavlik, I. (2005): Distribution of Mycobacterium avium Complex Isolates in Tissue Samples of Pigs Fed Peat Naturally 
Contaminated with Mycobacteria as a Supplement. Journal of Clinical Microbiology 43: 1261-1286.

Payeur, J.B. and Songer, J.G. (1992): Mycobacteriosis (Tuberculosis) in swine. Purdue University. Cooperative extension service. West Lafayette, Indiana, USA.

http://www.animalgenome.org/edu/PIH/99.html.

Phillips, C.J.; Foster, C.R.; Morris, P.A. and Teverson, R. (2003): The transmission of Mycobacterium bovis infection to cattle. Research in Veterinary Science 74: 1-15.

Pollock, J.M.; Girvin, R.M.; Lightbody, K.A.; Clements, R.A.; Neill, S.D.; Buddle, B.M. and Andersen, P. (2000): Assessment of defined antigens for the diagnosis of bovine tuberculosis in skin test-reactor cattle. The Veterinary Record 146: 659-665.

Raviglione, M.C. and Smith, I.M. (2007): XDR TuberculosisImplications for Global Public Health. New England Journal of Medicine 356: 656-659.

Sada, E.D.; Ferguson, L.E. and Daniel, T. (1990): An ELISA for the serodiagnosis of tuberculosis using 30,000 Da native antigen of Mycobacterium tuberculosis. Journal of Infectious Diseases 162: 928 - 931.

Salata, R.A.; Sanson, A.J.; Malhotra, I.J.; Wiker, H.J.; Harboe, M.; Phillipis, N.B. and Daniel, T.M. (1991): Purification and characteriz-ation of the 30,000 dalton native antigen of Mycobacterium tuberculosis and characterization of six monoclonal antibodies reactive with a major epitope of this antigen. Journal of Laboratory Clinical Medicine 118: 589-598.

Schorey, J.S.; Holsti, M.A.; Ratliff, T.L.; Allen, P.M. and Brown, E.J. (1996): Characterization of the fibronectin-attachment protein of Mycobacterium avium reveals a fibronectin-binding motif conserved among mycobacteria. Molecular Microbiology 21: 321-329.

Secott, T.E.; Lin, T.L. and Wu, C.C. (2001): Fibronectin attachment protein homologue mediates fibronectin binding by Mycobacterium avium subsp. paratuberculosis. Infection and Immunity 69: 2075-2082.

Siddiqi, S.H.; Heifets, L.B.; Cynamon, M.H.; Hooper, N.M.; Laszlo, A.; Libonati, J.P.; Lindholm-Levy, P.J. and Pearson, N. (1993): Rapid broth macrodilution method for determination of MICs for Mycobacterium avium isolates. Journal of Clinical Microbiology 31: 2332-2338. 
Silver, R.F.; Wallis, R.S. and Ellner, J.J. (1995): Mapping of T-cell epitopes of the 30KDa antigen of Mycobacterium bovis, strain Bacillus Calmette-Guiein in purified protein (PPD) positive individuals. Journal of Immunology 154: 4665-4674.

Smith, R.D. (1995): Veterinary Clinical Epidemiology: A problemOrinted Approach. CRC Press, Inc., Boca Ranton, Florida, USA, pp. 31-52.

Songer, J.G.; Bicknell, E.J. and Thoen, C.O. (1980): Epidemiological investigation of swine tuberculosis in Arizona. Canadian Journal of Comparative Medicine 44: 115-120.

Surujballi, O.P.; Romanowska, A.; Sugden, E.A.; Turcotte C. and Jolley, M.E. (2002): A fluorescence polarization assay for the detection of antibodies to Mycobacterium bovis in cattle sera. Veterinary Microbiology 87: 149-157.

Thoen, C.O.; Armbrust, A.L. and Hopkins, M.P. (1979): Enzyme-linked immunosorbant assay for detecting antibodies in swine infected with Mycobacterium avium. American Journal of Veterinary Research 40: 1096-1099.

Wayne, L.G. and Sramek, H.A. (1992): Agents of newly recognized or infrequently encountered mycobacterial diseases. Clinical Microbiology Reviews 5, 1-25.

Wiker, H.G. and Harboe, M. (1992): The antigen 85 complex: a major secretion product of Mycobacterium tuberculosis. Microbiology Reviews 56: 648-661.

Windsor, R.S.; Durrant, D.S. and Burn, K.J. (1984): Avian tuberculosis in pigs: Mycobacterium intracellulare infection in a breeding herd. The Veterinary Record 19: 497-500. 